\title{
Sea Hare Aplysia punctata (Mollusca: Gastropoda) Can Maintain Shell Calcification under Extreme Ocean Acidification
}

\author{
NICHOLAS CAREY ${ }^{1,2, *}$, SAM DUPONT ${ }^{3}$, AND JULIA D. SIGWART ${ }^{1}$ \\ ${ }^{1}$ Marine Laboratory, Queen's University Belfast, 12-13 The Strand, Portaferry, County Down \\ BT22 IPF, Northern Ireland, United Kingdom; ${ }^{2}$ Hopkins Marine Station, Stanford University, 120 \\ Ocean View Boulevard, Pacific Grove, California 93950; and ${ }^{3}$ Department of Biological and \\ Environmental Sciences, The Sven Lovén Centre for Marine Sciences - Kristineberg, University of \\ Gothenburg, Fiskebäckskil, 45178, Sweden
}

\begin{abstract}
Ocean acidification is expected to cause energetic constraints upon marine calcifying organisms such as molluscs and echinoderms, because of the increased costs of building or maintaining shell material in lower $\mathrm{pH}$. We examined metabolic rate, shell morphometry, and calcification in the sea hare Aplysia punctata under short-term exposure (19 days) to an extreme ocean acidification scenario ( $\mathrm{pH} 7.3, \sim 2800 \mu \mathrm{atm} p \mathrm{CO}_{2}$ ), along with a group held in control conditions ( $\mathrm{pH} 8.1, \sim 344 \mu$ atm $p \mathrm{CO}_{2}$ ). This gastropod and its congeners are broadly distributed and locally abundant grazers, and have an internal shell that protects the internal organs. Specimens were examined for metabolic rate via closed-chamber respirometry, followed by removal and examination of the shell under confocal microscopy. Staining using calcein determined the amount of new calcification that occurred over 6 days at the end of the acclimation period. The width of new, pre-calcified shell on the distal shell margin was also quantified as a proxy for overall shell growth. Aplysia punctata showed a 30\% reduction in metabolic rate under low $\mathrm{pH}$, but calcification was not affected. This species is apparently able to maintain calcification rate even under extreme low $\mathrm{pH}$, and even when under the energetic constraints of lower metabolism.
\end{abstract}

Received 15 December 2015; accepted 11 July 2016.

* To whom correspondence should be addressed. E-mail: nicholascarey@ gmail.com

Abbreviations: $\mathrm{M}$, dry tissue mass; $\mathrm{MO}_{2}$, mass-specific oxygen uptake rate; $\mathrm{OA}$, ocean acidification; $\mathrm{pH}_{\mathrm{T}}$, total scale $\mathrm{pH}$; $\mathrm{R}$, respiration rate; $\mathrm{S}$, salinity; $S_{B}$, shell border width; $S_{L}$, shell length; $S_{C}$, shell calcification width; T, temperature; TA, total alkalinity; $\mu$ atm $p \mathrm{CO}_{2}$, seawater partial pressure of $\mathrm{CO}_{2}$.
This finding adds to the evidence that calcification is a largely autonomous process of crystallization that occurs as long as suitable haeomocoel conditions are preserved. There was, however, evidence that the accretion of new, noncalcified shell material may have been reduced, which would lead to overall reduced shell growth under longerterm exposures to low $\mathrm{pH}$ independent of calcification. Our findings highlight that the chief impact of ocean acidification upon the ability of marine invertebrates to maintain their shell under low $\mathrm{pH}$ may be energetic constraints that hinder growth of supporting structure, rather than maintenance of calcification.

\section{Introduction}

Ocean acidification (OA), or the lowering of seawater $\mathrm{pH}$ by increased addition of dissolved atmospheric $\mathrm{CO}_{2}$, is the subject of much recent research. The potential effects of lower $\mathrm{pH}$ on calcifying marine species are perhaps the most prominent hypothesized impact. Lower $\mathrm{pH}$ and undersaturated calcium carbonate states may cause the shells of a host of marine species (molluscs, echinoderms, corals, coccolithophores, foraminiferans, calcifying algae) to undergo increased dissolution (Orr et al., 2005), or, at minimum, may increase the energetic costs of maintaining and growing such structures (Dupont et al., 2010).

In many invertebrates, the integrity of calcium carbonate structures directly impacts upon survival, as these provide physical protection from predators and environmental stressors such as wave action (Gaylord et al., 2011). For intertidal invertebrates such as bivalves and gastropods, these 
structures also allow the body to be sealed within an enclosed space, protecting against desiccation during periods of emersion in air. Compromising these abilities, therefore, could have ongoing effects upon populations of these species and the wider community for which they provide food, habitat, and services such as water filtration.

Compromised shell strength and composition under experimental OA has been demonstrated in numerous calcifying marine invertebrates (reviewed in Harvey et al., 2013). Compromised structural integrity under lower $\mathrm{pH}$ has also been shown in marine algae, including at a site of "natural OA," an area of volcanic outgassing of $\mathrm{CO}_{2}$ that is thought to closely mimic future OA conditions (Newcomb et al., 2015). Studies on the invertebrates in this and similar "natural OA" sites show much decreased structural integrity of calcified parts (Rodolfo-Metalpa et al., 2011), with consequences for survival and community dynamics (HallSpencer et al., 2008; Kroeker et al., 2011).

The additional energetic burden of maintaining calcified structures in lower $\mathrm{pH}$ could be an important factor for ongoing survival and reproduction of populations. The costs of maintenance metabolism are the baseline required for survival; important processes such as reproduction and growth require fuel above this baseline. In the absence of energetic trade-offs, or acquisition of additional energy, the added burden of maintaining net calcification under OA will impact upon this portion of the energetic budget. Even without this added burden, OA is frequently accompanied by physiological changes and altered metabolic rates, both decreases (Christensen et al., 2011) and increases (Carey et al., 2016), and so the energetic consequences of OA may be important beyond those upon the calcification pathway. In addition, altered energetics are closely coupled to feeding rates, and, therefore, OA may have ongoing ecological effects (Burnell et al., 2013).

Sea hares are anaspidean gastropods or sea slugs that are globally distributed in tropical and temperate shallow waters and the intertidal. The biology of this group is well known from Aplysia californica (Dionísio et al., 2013), a model organism for neurobiology (e.g., Sattelle and Buckingham, 2006; Kandel et al., 2014). Its congener Aplysia punctata (Cuvier, 1803) is common in the north Atlantic in shallow waters and the intertidal. Its distribution is broader than many other Northeastern Atlantic shallow water molluscs - from the Mediterranean to as far north as Greenlandand it is the largest anaspidean species in polar waters. Aplysia species are voracious feeders, consuming up to a third of their body weight of algae each day (Carefoot, 1987).

Most sea hares, including A. punctata, possess an internal shell. While the shell is thin and small in comparison to other gastropods, it serves to protect the heart and other internal organs (Beesley et al., 1998). In larger specimens, the shell may reach over $6 \mathrm{~cm}$ in length (Hunt, 1877), and shows accretionary growth bands analogous to those seen on the shelves of bivalves or other molluscs (e.g., Fig. 1B) (Usuki, 1981). The shell in Aplysia is formed primarily from aragonite deposited within a protein matrix (Pedrozo et al., 1997; Tonejc et al., 2014). Aragonite is a form of calcium carbonate that is particularly susceptible to dissolution under lower seawater pH (Mucci, 1983).

In a short-term experiment, we exposed Aplysia punctata to a reduction in seawater $\mathrm{pH}$ from ambient conditions $(\sim 8.1)$ to 7.3 . This $\mathrm{pH}$ represents an extreme scenario for the end of this century, under the more pessimistic emissions scenarios (IPCC, 2014); that is, a predicted decrease in mean seawater $\mathrm{pH}$ of around 0.4 , plus an added decrease, which would be expected due to natural $\mathrm{pH}$ variability in shallow or intertidal environments. In tidepools, short-term variation in $\mathrm{pH}$ can be considerable (up to 1.78 units) due to diurnal variations in calcification, net primary production, and temperature (Kwiatkowski et al., 2016). In upwelling areas, pH can vary diurnally by up to 0.36 (Frieder et al., 2012). In a Baltic fjord close to where the present study was conducted, the seasonal variability was $\sim 0.6$, with considerable changes of $0.3-0.4$ occurring over timescales of days (Thomsen et al., 2010; Melzner et al., 2013). Another study in the same region documented, over 3 weeks, a mean diurnal amplitude in $\mathrm{pH}$ of 0.34 , but with extreme diurnal fluctuations of up to 0.6 , and a minimum $\mathrm{pH}$ of 7.26 (Saderne et al., 2013). That study was conducted in a shallow algal and seagrass habitat, typical of that in which A. punctata is found (Carefoot, 1987; Ouisse et al., 2012). Therefore, the chosen low $\mathrm{pH}$ treatment of 7.3 is likely close to the minimum $\mathrm{pH}$ experienced by this species in this region, albeit periodically. Ongoing maintenance at this $\mathrm{pH}$ represents an extreme but plausible near-future scenario, with the compounded changes of decreased mean $\mathrm{pH}$ plus that due to natural variability.

This is the first study to examine the responses of Aplysia to ocean acidification. We expected that $A$. punctata would show the typical responses of shallow water and intertidal organisms to short-term experimental exposure to lowered $\mathrm{pH}$ : a decrease in metabolic rate. Given this response, along with the aragonitic composition and extremely thin and fragile nature of the $A$. punctata shell, we hypothesized that low $\mathrm{pH}$ would also have substantial impacts upon shell growth and calcification.

\section{Materials and Methods}

\section{Experimental set-up}

Specimens of Aplysia punctata, ranging in size from 0.5 $\mathrm{cm}$ to $5 \mathrm{~cm}$ extended body length, were collected in Gullmar Fjord, Sweden, in January 2014, and held in natural flowthrough seawater at the Sven Lovén Centre for Marine Sciences, Kristineberg, University of Gothenburg. They were maintained in these conditions for several weeks and 


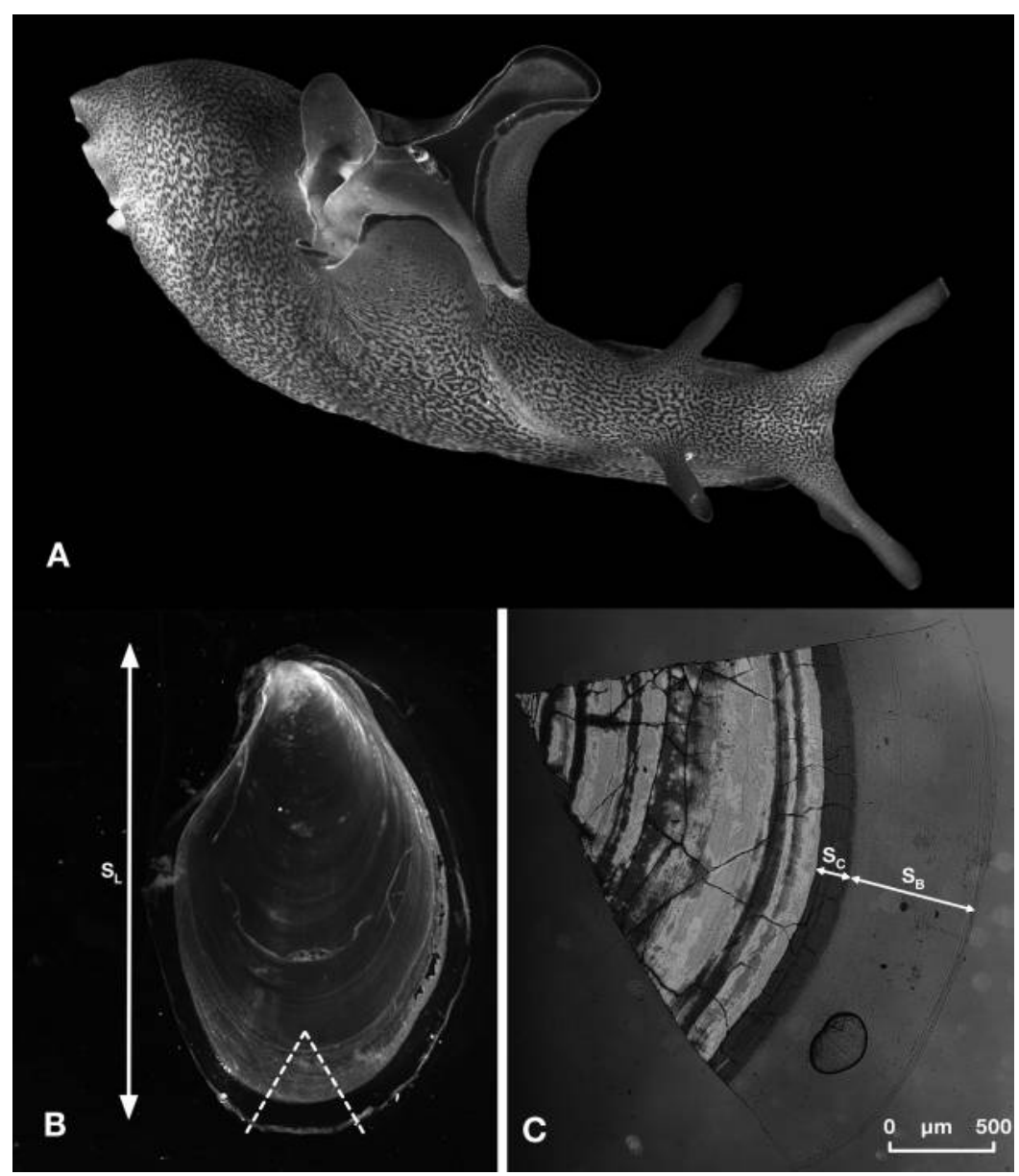

Figure 1. Sea hare Aplysia punctata. (A) Live specimen of A. punctata from Flamborough, England. The shell can be partially seen through the small oval opening in the mantle under the dosal parapodia. (Photo: Ian F. Smith) (B) A whole shell from a specimen held in control $\mathrm{pH}$, as photographed under an optical microscope. Dashed lines show approximate location of sections that were subsequently removed for mounting and examination via confocal microscopy. Shell length $\left(\mathrm{S}_{\mathrm{L}}\right)$ was measured from these photographs as the maximum longitudinal diameter, using ImageJ. In this example, $\mathrm{S}_{\mathrm{L}}=8.26 \mathrm{~mm}$. (C) A mounted section from a specimen held in low $\mathrm{pH}$, as photographed under confocal microscopy. Two images have been combined: an optical image and an image under UV light. The light gray region (originally fluorescing green under confocal microscopy images) indicates calcein-stained calcium carbonate. Shell calcification width $\left(\mathrm{S}_{\mathrm{C}}\right)$ represents new calcification in the period after staining, and shell border width $\left(S_{B}\right)$ is the width of the non-calcified shell border protein matrix. Three measurements of each were taken perpendicular to the shell curvature, then averaged to give a single value of each per specimen.

fed ad libitum on fresh, locally collected Ulva lactuca and Palmaria palmata algae. The specimens were split into two groups with the total size range represented in each; 16 were assigned to the low $\mathrm{pH}$ treatment, and 16 to control $\mathrm{pH}$. They were transferred to $30-1$ glass tanks supplied with flowthrough seawater $\left(7{ }^{\circ} \mathrm{C}, 32.4 \%\right.$ salinity $)$ at a rate of 1 liter $\mathrm{min}^{-1}$, held in a constant temperature room with a 10-h/14-h light/dark regime approximating local conditions, and fed ad libitum on P. palmata. Treatment tank water was kept at $100 \%$ dissolved oxygen concentrations at all times $v i a$ an air supply bubbled through a ceramic diffuser. There was a single tank per treatment; therefore, scope for statistical inference of any treatment effects must be considered with caution. Without treatment replication, results are prone to type I errors, where a discrepancy between groups may be falsely attributed to treatment effect (Heffner et al., 1996). However, lack of treatment replication does not belie the veracity of observations within that experimental group (Oksanen, 2001).

The low $\mathrm{pH}$ treatment was gradually adjusted from control $\mathrm{pH}(\sim 8.1)$ to the low $\mathrm{pH}$ setpoint (7.3) over 2 days. After 9 subsequent days' maintenance in these conditions, specimens were transferred to $100-\mathrm{ml}$, clear glass jars containing the appropriate treatment water in groups while keeping biomass relatively equal in each to avoid hypoxic conditions (i.e., only one large specimen per jar, up to 4 
Table 1

Carbonate system parameters $( \pm S D)$

\begin{tabular}{|c|c|c|c|c|c|c|c|c|}
\hline Treatment & $\mathrm{T}\left({ }^{\circ} \mathrm{C}\right)$ & $\mathrm{pH}_{\mathrm{T}}$ & $\mathrm{S}$ & TA & $p \mathrm{CO}_{2}(\mu \mathrm{atm})$ & $\mathrm{TC}(\mu \mathrm{mol} / \mathrm{kg})$ & $\Omega_{\mathrm{Ca}}$ & $\Omega_{\mathrm{Ar}}$ \\
\hline Control pH & $7.1 \pm 0.2$ & $8.12 \pm .03$ & $32.8 \pm 0.2$ & $2372 \pm 38$ & $344 \pm 29$ & $2185 \pm 29$ & $3.35 \pm 0.27$ & $2.12 \pm 0.17$ \\
\hline Low pH & $7.2 \pm 0.2$ & $7.27 \pm .04$ & $32.8 \pm 0.2$ & $2418 \pm 42$ & $2803 \pm 440$ & $2520 \pm 54$ & $0.57 \pm 0.1$ & $0.36 \pm 0.06$ \\
\hline
\end{tabular}

Total dissolved inorganic carbon (TC), $p \mathrm{CO}_{2}$, and saturation state for calcite and aragonite $\left(\Omega_{\mathrm{Ca}}\right.$ and $\left.\Omega_{\mathrm{Ar}}\right)$ were calculated from total scale pH (pH $\left.\mathrm{T}_{\mathrm{T}}\right)$ and total alkalinity (TA), using $\mathrm{CO} 2$ calc ver. 1.0 for Mac OS $\mathrm{X}$.

$\mathrm{S}$, salinity; T, temperature; $\mu$ atm $p \mathrm{CO}_{2}$, seawater partial pressure of $\mathrm{CO}_{2}$.

small specimens per jar, and 6 jars in total). Calcein stock solution was added to each to a concentration of $5 \mathrm{mg} \mathrm{l}^{-1}$, and the jars were sealed and placed back in treatment tanks. Calcein is a fluorescent chromophore that binds to calcium and has been used extensively to visualize skeletal structures and calculate growth rates in a range of vertebrates and invertebrates (Du et al., 2001; Russell and Urbaniak, 2004). It is non-toxic and does not interfere with normal growth (Russell and Urbaniak, 2004). Water was changed 4 times daily, calcein staining was repeated as above with each replacement, and animals were kept in these jars for 48 hours. Jars were agitated regularly to avoid stratification. Oxygen concentration and $\mathrm{pH}$ were monitored in jars routinely and found to be close to tank maintenance conditions at all times. After removal from the sealed jars, animals were returned to the open treatment tanks and held for a further 6 days. Specimens were thus held for a total of 19 days: 11 days of maintenance (including 2 days to reach setpoints for low $\mathrm{pH}$ treatment), 2 days of staining, and 6 days of further maintenance. From available data on the congener Aplysia californica (Peretz and Adkins, 1982), this regime was judged long enough in which to observe substantial shell growth, even given the smaller size of $A$. punctata and lower environmental temperature.

\section{Seawater chemistry}

Temperature (T), salinity $(\mathrm{S})$, and $\mathrm{pH}$ (total scale $\left(\mathrm{pH}_{\mathrm{T}}\right)$ ) were measured daily throughout maintenance. Total alkalinity (TA) was determined every 3 days. Seawater carbonate chemistry was maintained using a computerized feedback system (AquaMedic, Bissendorf, Germany) that regulates $\mathrm{pH}$ by addition of pure $\mathrm{CO}_{2}$ gas directly into the seawater $( \pm 0.02 \mathrm{pH}$ units). Total alkalinity was determined on filtered water samples with a titration system (TitroLine alpha plus; SI Analytics GmbH, Mainz, Germany). Total scale $\mathrm{pH}$ was measured using a Metrohm (827 $\mathrm{pH}$ lab) electrode and adjusted for $\mathrm{pH}$ measurements on the total scale using Tris (Tris/HCl) and AMP (2-aminopyridine/ $\mathrm{HCl}$ ) buffer solutions with a salinity of 32 , provided by Unité d'Océanographie Chimique, Université de Liège, Belgium. Seawater carbonate system speciation (Table 1) was calculated from $\mathrm{pH}_{\mathrm{T}}$, and $\mathrm{TA}$ was determined by $\mathrm{CO} 2 \mathrm{calc}$ ver. 1.0 for Mac OS X, using the dissociation constants of Mehrbach et al. (1973), as refitted by Dickson and Millero (1987). Seawater chemistry parameters were stable throughout the maintenance period, and in the low $\mathrm{pH}$ treatment the saturation states for calcite and aragonite were highly undersaturated (Table 1).

\section{Respirometry experiments}

Oxygen consumption was determined via closed-chamber respirometry, as previously used on marine invertebrates (Carey et al., 2014; Carey and Sigwart, 2014). Due to the low metabolic rates of invertebrates, particularly in smaller specimens and under low temperatures, closedchamber techniques are considered the most reliable method of determining oxygen uptake rates (Lighton, 2008). The food source was removed $24 \mathrm{~h}$ before experiments. To avoid interference with the oxygen probe, and to prevent specimens from attaching to the inner surface of the respirometry chamber and sustaining possible injury during removal at the end of the experiments, specimens were placed individually in a nylon mesh envelope, allowed to become accustomed to this for one hour, then placed into cylindrical respirometry chambers that were then sealed while under water within the treatment tanks. An oxygen probe (FOXY Systems; Ocean Optics, Dunedin, FL), which was connected to a PC laptop that recorded oxygen readings at intervals of 1 second, was inserted. The chambers were placed in a temperature-controlled tank situated on a laboratory "rocker" platform that rotated approximately once every $2 \mathrm{~s}$. Oxygen recordings showed that this action was sufficient to keep chambers internally mixed. Chambers ranged in volume from approximately $100 \mathrm{ml}$ to $400 \mathrm{ml}$. Six trials were run simultaneously for up to $3 \mathrm{~h}$, or until an approximate $10 \%$ decrease from the initial concentrations of $100 \%$ oxygen saturation was observed. Six control runs, which were identical except for the absence of a specimen, were conducted to determine microbial oxygen consumption and a correction based on this applied to specimen runs.

After each trial, chambers were dried externally and weighed. The specimen was removed and blotted dry, and its wet mass determined. Dry chamber mass and specimen wet mass were subtracted from the total chamber mass to 
determine internal water mass; this figure was converted to volume using the seawater density for the appropriate temperature and salinity (Fofonoff and Millard, 1983). Each individual trace was examined and a stable representative section selected to determine routine oxygen consumption $\left(\mathrm{R}, \mathrm{mg} \mathrm{h}^{-1}\right)$ for each individual. From these data, the massspecific oxygen uptake rate $\left(\mathrm{MO}_{2} \mathrm{mg} \mathrm{h}^{-1} \mathrm{~g}^{-1}\right)$ was determined for each individual as $\mathrm{R}$ divided by dry mass $(\mathrm{M})$.

\section{Shell morphometry}

After respirometry, the internal shell of each specimen was dissected out. The remainder of the specimen was dried for $24 \mathrm{~h}$ at $60{ }^{\circ} \mathrm{C}$ and weighed to obtain dry tissue mass (M, g). The shell was photographed under an optical microscope (e.g., Fig. 1B). A small section from the anterior most part of the shell was then removed (Fig. 1C); this region is the area of maximum shell growth and least dorsoventral inflation, allowing the sampled section to be mounted flat on a glass microscope slide for examination. These sections were examined under a confocal laser-scanning microscope (Leica TCS SP5; Leica, Wetzlar, Germany) to determine the extent of calcein staining, and photographed under both full-spectrum and UV lights.

Three distinct regions of the shell were identifiable: the central part of the shell, already calcified during the calcein staining treatment; newly crystallized calcium (unstained); and the uncalcified growing shell margin (Fig. 1C). Quantitative measurements were determined from digital images via ImageJ. Using images captured with confocal microscopy, we measured the widths of uncalcified shell border $\left(S_{B}\right)$ and new calcification $\left(\mathrm{S}_{\mathrm{C}}\right)$, taking the mean of three radii to give a single reported value of $S_{B}$ and $S_{C}$ for each specimen. Total shell length $\left(\mathrm{S}_{\mathrm{L}}\right)$ was measured as the maximum longitudinal diameter from photographs of whole shells.

\section{Data analysis}

Analysis of covariance (ANCOVA) was used to examine differences between metabolic rate, measured as respiration rate $(\mathrm{R})$, across $\mathrm{pH}$ treatments with mass $(\mathrm{M})$ as covariate. Multiple regression was used to examine the effects upon shell calcification $\left(\mathrm{S}_{\mathrm{C}}\right)$ of the other metrics $(\mathrm{pH}$, dry tissue mass, mass-specific oxygen uptake rate, shell length, and shell border width). Pairwise linear dependence between morphological and physiological parameters (dry tissue mass, shell length, shell border width, shell calcification width, and mass-specific oxygen uptake rate) was assessed using Pearson correlations.

Statistical analyses were conducted in R (R Core Development Team, 2015). All data met the normality and homogeneity of variance assumptions of ANCOVA and ANOVA tests (Shapiro-Wilk and Bartlett tests, respectively). Measurements of variability are Standard Error (SE), unless otherwise noted.

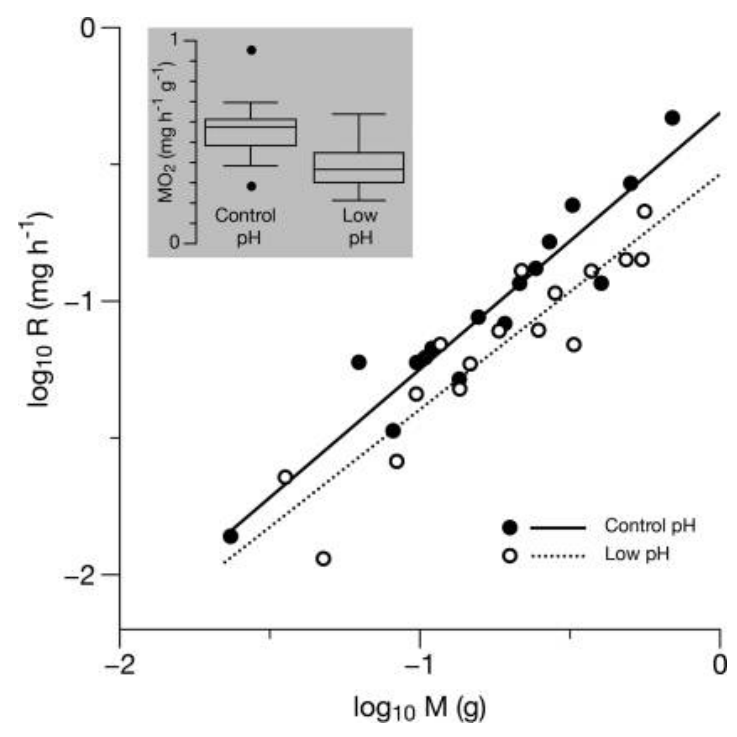

Figure 2. Oxygen uptake in Aplysia punctata under control and low $\mathrm{pH}$. Scatter plot shows the relationship between mass and metabolic rate through linear regressions on $\log _{10}$-transformed data for individual oxygen uptake rate $\left(\mathrm{R}, \mathrm{mg} \mathrm{h}^{-1}\right)$ against dry tissue mass $(\mathrm{M}, \mathrm{g})$. The black line and solid circles are control $\mathrm{pH}$, the dashed line and open circles are low $\mathrm{pH}$. Regression equations: control $\mathrm{pH}, \mathrm{y}=0.94 \mathrm{x}-0.31, R^{2}=0.90$; low $\mathrm{pH}$, $\mathrm{y}=0.86 \mathrm{x}-0.54, R^{2}=0.85$. Inset shows the same data expressed as summary boxplots of mass-specific oxygen uptake rates $\left(\mathrm{MO}_{2} ; \mathrm{mg} \mathrm{h}^{-1} \mathrm{~g}^{-1}\right)$ : medians (lines), interquartile ranges (boxes), $1.5 \times$ extended interquartile ranges (whiskers), and outliers.

\section{Results}

Specimens ranged in mass (dry tissue mass (M)) from $0.023 \mathrm{~g}$ to $0.694 \mathrm{~g}$. Sizes in the experimental groups did not significantly differ in M (one-way ANOVA, $F_{1,30}=0.08$, $P=0.78$ ) or shell length (one-way ANOVA, $F_{1,30}=0.04$, $P=0.84)$.

Oxygen uptake rates $(\mathrm{R})$ were significantly reduced under low $\mathrm{pH}$; R differed between control and acidified treatments (ANCOVA, $F_{1,28}=13.23, P=0.001$ ). Regression slope values (i.e., the metabolic scaling exponent, " $\boldsymbol{b}$ ") were not significantly different between $\mathrm{pH}$ levels $\left(F_{1,28}=0.37, P=\right.$ $0.55)$, the actual values being 0.94 in control $\mathrm{pH}$ and 0.86 in low $\mathrm{pH}$ (Fig. 2). At the $\log _{10}$-midpoint of the mass range $(0.127 \mathrm{~g})$, the uptake $\left(\mathrm{mg} \mathrm{h}^{-1}\right)$ predicted from the models was $0.071( \pm 0.011)$ in control $\mathrm{pH}$ and $0.050( \pm 0.009)$ in low $\mathrm{pH}$, a decrease of $30 \%$.

Figure 3 shows a correlation matrix of all measured parameters. Because $\mathrm{pH}$ had no effect on any metric except the mass-specific oxygen uptake rate, correlation tests were conducted on the entire dataset. Shell calcification $\left(\mathrm{S}_{\mathrm{C}}\right)$ was not significantly correlated with total shell length (Pearson correlation, $r=-0.10, P=0.59)$, shell border width $(r=$ $0.12, P=0.51)$, mass-specific oxygen uptake rate $(r=0.09$, $P=0.62)$, or dry-tissue mass $(r=-0.06, P=0.74)$. The only significant correlations were between the morphological parameters of mass, $\mathrm{S}_{\mathrm{L}}$, and $\mathrm{S}_{\mathrm{B}}\left(\mathrm{S}_{\mathrm{L}}: \mathrm{S}_{\mathrm{B}}, r=0.73, P<\right.$ 

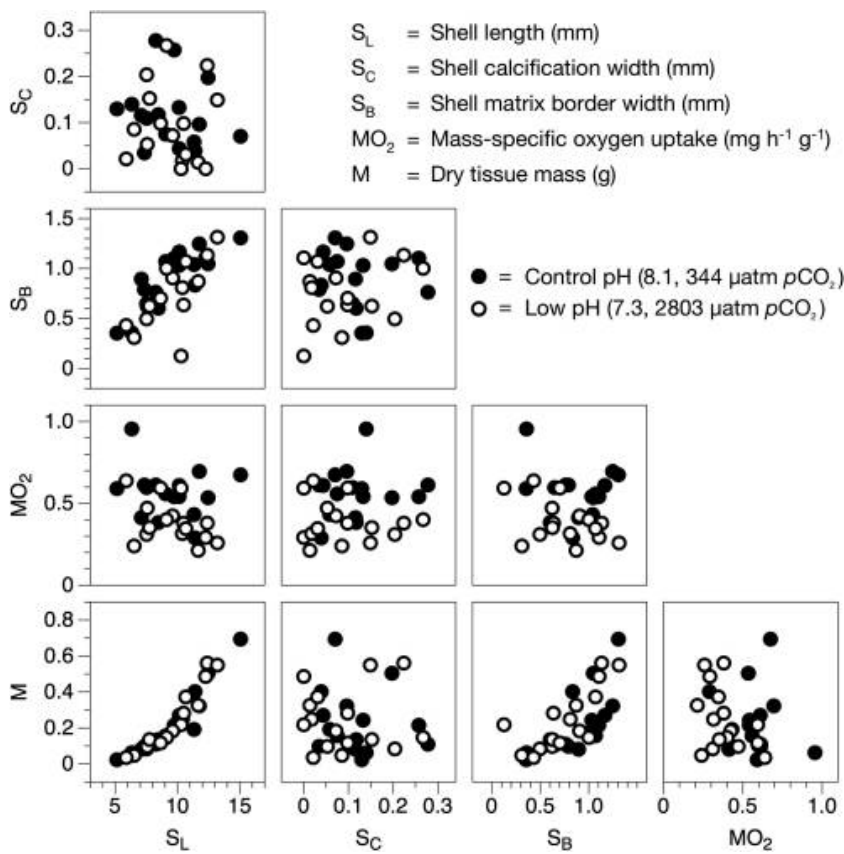

Figure 3. Correlation matrix for morphological and physiological measurements of Aplysia punctata. Solid circles are control $\mathrm{pH}$, open circles are low $\mathrm{pH}$. M, dry tissue mass $(\mathrm{g}) ; \mathrm{MO}_{2}$, mass-specific oxygen uptake $\left(\mathrm{mg} \mathrm{h}^{-1} \mathrm{~g}^{-1}\right) ; \mathrm{S}_{\mathrm{B}}$, shell matrix border width $(\mathrm{mm}) ; \mathrm{S}_{\mathrm{C}}$, shell calcification width $(\mathrm{mm}) ; \mathrm{S}_{\mathrm{L}}$, total shell length $(\mathrm{mm}) ; \mu \mathrm{atm} p \mathrm{CO}_{2}$, seawater partial pressure of $\mathrm{CO}_{2}$.

$0.0001 ; \mathrm{S}_{\mathrm{B}}: \mathrm{M}, r=0.69, P<0.0001 ; \mathrm{S}_{\mathrm{L}}: \mathrm{M}, r=0.94, P<$ 0.0001). This last relationship of $M$ to $S_{L}$ was best described by an allometric power law: $\mathrm{M}=15.61 \mathrm{~S}_{\mathrm{L}}{ }^{0.30}, r^{2}=0.96$. Unlike the case with $\mathrm{R}$ (Fig. 2), $\mathrm{MO}_{2}$ and $\mathrm{M}$ were not significantly correlated, most likely due to the mass-scaling exponent values (0.94 and 0.86$)$ being close to isometric.

Shell calcification width $\left(\mathrm{S}_{\mathrm{C}}\right)$ was not significantly different between control and low $\mathrm{pH}$ treatments (one-way ANOVA, $\left.F_{1,30}=0.83, P=0.37\right)$. The average length of new calcification (over 6 days) was $\mathrm{S}_{\mathrm{C}}=0.12( \pm 0.02) \mathrm{mm}$ in control pH and $\mathrm{S}_{\mathrm{C}}=0.09( \pm 0.02) \mathrm{mm}$ in low $\mathrm{pH}$. Only two specimens showed no detectable calcification, both in the low $\mathrm{pH}$ treatment. Visual inspection through dissection and brightness of fluorescence showed no obvious qualitative differences between the two treatment groups in overall shell calcification. Shell border $\left(S_{B}\right)$, or the width of uncalcified material on the shell margin, and the combined total growth $\left(\mathrm{S}_{\mathrm{C}}+\mathrm{S}_{\mathrm{B}}\right)$ did not differ between $\mathrm{pH}$ treatments under ANOVA analysis (one-way ANOVAs; $\mathrm{S}_{\mathrm{B}}, F_{1,30}=1.46$, $\left.P=0.24 ; \mathrm{S}_{\mathrm{C}}+\mathrm{S}_{\mathrm{B}}, F_{1,30}=1.85, P=0.18\right)$.

Under multiple regression analysis, $\mathrm{S}_{\mathrm{C}}$ was not associated with any significant interactions with the other variables $\left(\mathrm{MO}_{2}, \mathrm{M}, \mathrm{S}_{\mathrm{L}}, \mathrm{S}_{\mathrm{B}}\right.$, or $\left.\mathrm{pH}\right)$ (Table 2; Fig. 3). Alternative models were assessed using the step function in $\mathrm{R}$ (R Core Development Team, 2015) to perform stepwise regression backwards from the full model. The minimal adequate
Table 2

Multiple regression model of shell calcification $\left(S_{C}, \mathrm{~mm}\right)$ against other physiological and morphological factors

\begin{tabular}{lrccccc}
\hline \hline & Intercept & SE & SS & df & $F$ & $\boldsymbol{P}$ \\
\hline $\mathrm{S}_{\mathrm{C}}$ & 0.199 & 0.147 & & & & \\
$\mathrm{pH}$ & -0.010 & 0.037 & 0.00517 & 1,26 & 0.784 & 0.384 \\
$\mathrm{M}$ & 0.117 & 0.242 & 0.00054 & 1,26 & 0.082 & 0.777 \\
$\mathrm{MO}_{2}$ & 0.004 & 0.111 & 0.00003 & 1,26 & 0.004 & 0.949 \\
$\mathrm{~S}_{\mathrm{L}}$ & -0.021 & 0.019 & 0.00306 & 1,26 & 0.464 & 0.502 \\
$\mathrm{~S}_{\mathrm{B}}$ & 0.100 & 0.075 & 0.01088 & 1,26 & 1.651 & 0.210 \\
\hline $\mathrm{S}_{\mathrm{C}}$ & 0.148 & 0.059 & & & & \\
$\mathrm{~S}_{\mathrm{L}}$ & -0.014 & 0.009 & 0.00187 & 1,29 & 0.312 & 0.581 \\
$\mathrm{~S}_{\mathrm{B}}$ & 0.106 & 0.066 & 0.01548 & 1,29 & 2.585 & 0.119 \\
\hline
\end{tabular}

Top six rows $=$ full model; bottom three rows $=$ minimal adequate model after stepwise regression backwards from the full model, using Akaike information criterion (AIC).

$\mathrm{M}$, dry tissue mass $(\mathrm{g}) ; \mathrm{MO}_{2}$, mass-specific oxygen uptake $\left(\mathrm{mg} \mathrm{h}^{-1}\right.$ $\left.\mathrm{g}^{-1}\right) ; \mathrm{S}_{\mathrm{L}}$, total shell length $(\mathrm{mm}) ; \mathrm{S}_{\mathrm{B}}$, shell border width $(\mathrm{mm}) ; \mathrm{SE}$, standard error; SS, sum of squares; df, degrees of freedom; $F, F$-statistic; $P$, probability.

model $\left(\mathrm{S}_{\mathrm{C}} \sim \mathrm{S}_{\mathrm{L}}+\mathrm{S}_{\mathrm{B}}\right)$ did not contain any significant interactions (Table 2). Shell border width as a proportion of total shell length $\left(\mathrm{S}_{\mathrm{L}}\right)$ was consistent across body size (around $8 \%$ to $9 \%$ ), and while the $\mathrm{S}_{\mathrm{B}}: \mathrm{S}_{\mathrm{L}}$ proportion in low $\mathrm{pH}(7.8 \pm 0.6 \%)$ was less than in control $\mathrm{pH}(9.4 \pm 0.5 \%)$, this was marginally not significant (Kruskal-Wallis $\mathrm{H}$ test $=$ $3.41, P=0.06$ ). Similarly, under multiple regression analysis, $\mathrm{pH}$ as an effect on $\mathrm{S}_{\mathrm{B}}$ was marginally non-significant $\left(F_{1,28}=3.41, P=0.075\right)$.

\section{Discussion}

Aplysia punctata showed no decrease in calcification of new shell material, although there was a significantly reduced metabolic rate under low $\mathrm{pH}$. This is despite both the calcite and aragonite saturation states being highly undersaturated in experimental water chemistry conditions (Table 1), which might be expected to result in active dissolution of unprotected calcified material. The low $\mathrm{pH}$ treatment of 7.3 that we chose was purposely extreme, but represents a plausible level that may be sustained for periods in this marine habitat in the near future, given the predicted decreases in mean $\mathrm{pH}$ of around 0.4 under pessimistic emissions scenarios (IPCC, 2014), and the substantial short-term natural variability in $\mathrm{pH}$ in other Baltic fjords of 0.4 to 0.6 (Thomsen et al., 2010; Melzner et al., 2013; Saderne et al., 2013). Our expectation was that increased costs of acid-base regulation in low $\mathrm{pH}$ would impact upon the calcification of the shell of A. punctata. In contrast, under this extreme low $\mathrm{pH}$ regime, and even when metabolic functioning was reduced, A. punctata maintained normal shell calcification.

To our knowledge, only one other study has examined 
responses under ocean acidification of Aplysia or any other sea hare species (the clade Anaspidea); low pH was shown to increase mortality in the embryos of a tropical sea hare (Davis et al., 2013). One additional study found increased respiratory pumping in Aplysia californica in seawater into which $\mathrm{CO}_{2}$ was bubbled, causing extreme and rapid hypercapnia (a decrease to $5.9 \mathrm{pH}$ over $10 \mathrm{~min}$; Croll, 1985). While the respiratory pumping rate is a proxy for metabolic rate, it is likely that the reported effect was a stress response to extreme low $\mathrm{pH}$, or the animal attempting to expel noxious water from its mantle cavity.

Oxygen consumption is considered a proxy for metabolic rate because animals typically do not store substantial amounts of oxygen; they meet their oxygen requirements by taking it from the surrounding environment. Oxygen consumption may not entirely represent metabolic rate because it does not account for anaerobic processes, but in most animals anaerobic metabolism is not sustained for prolonged periods and does not make up a substantial portion of standard or resting metabolic rates; it is also minimal at times when oxygen is plentiful. Therefore, oxygen uptake rate in near-saturated conditions of oxygen is considered an excellent proxy for metabolic rate in aquatic breathers (Lighton, 2008). In our experiment, low $\mathrm{pH}$ caused an approximate $30 \%$ decrease in metabolism in Aplysia punctata. Given the very high feeding rates of sea hares (Carefoot, 1987; Dionísio et al., 2013), any ongoing impact upon metabolic demand has the potential to alter feeding patterns and, speculatively, have cascading ecological effects. Metabolic depression is a common effect of exposure to low $\mathrm{pH}$ in intertidal animals, and may be related to the need to conserve energy during periodic hypercapnic conditions (Christensen et al., 2011). Interestingly, under two other common intertidal stressors, hypoxia and air-exposure, $A p$ lysia californica will decrease its heart rate, and presumably its metabolic rate, in order to conserve energy (Dieringer et al., 1978; Carefoot, 1987). The result that we saw here may therefore represent a typical short-term response, and exposure over longer timescales may result in different metabolic responses and different conclusions as to the overall effect of OA upon metabolic rate. In another gastropod, a 14-month acclimation to OA resulted in consistent metabolic reductions (Queirós et al., 2015), but under similarly long-term acclimation no ongoing metabolic response was observed in several echinoderms (Appelhans et al., 2014; Moulin et al., 2015; Suckling et al., 2015).

The metabolic scaling exponent $(\boldsymbol{b})$ represents the increasing metabolic efficiency with body size; the values that we found for $\boldsymbol{b}(0.94$ and 0.86$)$ are somewhat higher than the previously reported value of 0.76 for A. punctata (Marsden et al., 2012). That study, however, used a narrow size range, covering less than one order of magnitude $(0.25$ to $0.81 \mathrm{~g}$ dry mass, estimated from fig. 3 of Marsden et al., 2012) compared to a broader size range that was examined here
$(0.023 \mathrm{~g}$ to $0.694 \mathrm{~g})$. Estimates of $\boldsymbol{b}$ are highly sensitive to limited size ranges (Sokal and Rohlf, 1995), as reflected in the large difference in $r^{2}$ values $\left(r^{2}=0.53\right.$ in Marsden et al., 2012 vs. 0.90 and 0.85 in the present study). In addition, $\boldsymbol{b}$ is known to be somewhat plastic to environmental and biological factors (Glazier, 2009; Carey and Sigwart, 2014), so it may vary intraspecifically for other reasons. Similarly high scaling exponents have been reported in other Aplysia species; in A. dactylomela, $\boldsymbol{b}=0.93$ (Carefoot, 1988), and in $A$. brasiliana, $\boldsymbol{b}=0.89$ to 0.91 (Donovan et al., 2006), and may be related to their high physical activity and metabolic rates (Glazier, 2010; Carey et al., 2013). The present study, with a wider size range, provides the most robust estimate of metabolic scaling in A. punctata, or similar species, to date. However, the maximum size that we examined was around $7 \mathrm{~g}$ wet mass, while this species can reach $130 \mathrm{~g}$ (Carefoot, 1987), so there is ample scope for improved estimates.

Few studies have quantified metabolic rate in Aplysia. Those that have done so utilized specimens of different sizes and examined them in different temperatures, making direct comparisons of rates difficult. The one other study that has examined A. punctata (Marsden et al., 2012), utilizing data from 8 specimens collected in 1977, documented rates approximately half those that we observed here when converted to common body mass and temperature (conversions not shown). The disparity could be connected to seasonal, regional, feeding state, or experimental differences, all of which can introduce interspecific variability in metabolic rate. Two other studies examined metabolic rates in different Aplysia species, reporting rates of approximately 25\% (Carefoot, 1988) and 75\% (Donovan et al., 2006) of those we report here in A. punctata after conversion to common mass and temperature (conversions not shown). These were, however, much larger species, up to $0.5 \mathrm{~kg}$ live mass in Donovan et al., and examined at tropical temperatures of $25{ }^{\circ} \mathrm{C}$, so differences would be expected, even after conversion to common mass and temperature.

Aplysia are relatively large animals, and their main predator avoidance strategies are unpalatability or ejection of an ink that contains a toxin (Carefoot, 1987). The internal shell is small and not particularly robust, but does provide protection for internal organs (Beesley et al., 1998). The importance of this function and the structure of the shell in general in sea hares has not been well studied. Shell size among our sampled specimens was closely correlated with body mass, according to the power law, $\mathrm{S}_{\mathrm{L}}=15.61 \mathrm{M}^{0.30}$. Similar scaling relationships have been reported in Aplysia californica $\left(\mathrm{S}_{\mathrm{L}}=5.1 \mathrm{M}^{0.33}\right.$, Peretz and Adkins, 1982) and Aplysia fasciata $\left(\mathrm{S}_{\mathrm{L}}=9.23 \mathrm{M}^{0.27}\right.$, Krakauer, 1974), with the difference in intercepts best explained by different relative proportions of shell to tissue in different species. Shell calcification rate was here found to be size-independent, which agrees with shell growth patterns in A. californica 
(Peretz and Adkins, 1982). That study observed growth of $0.23 \mathrm{~mm} \mathrm{day}^{-1}$, but the much lower rate observed here $(0.02$ $\left.\mathrm{mm} \mathrm{day}{ }^{-1}\right)$ could be largely explained by the temperature difference $\left(7^{\circ} \mathrm{C}\right.$ vs. $\left.16^{\circ} \mathrm{C}\right)$.

The constant rate of calcification across both animal size and $\mathrm{pH}$ treatment, despite differences in shell margin widths and metabolism, suggests that calcification in Aplysia may be a largely autonomous process of crystallization that occurs as long as suitable conditions are present, or that the process is prioritized within the energy budget. During growth, shell is accreted as a proteinaceous matrix that includes dolomite particles that are the crystallization nuclei for calcification (Pedrozo et al., 1997; Tonejc et al., 2014). Crystallization occurs as long as appropriate cellular $\mathrm{pH}$ is maintained around these nuclei and, from our data, it appears that Aplysia punctata can adequately control cellular acid-base balance even in the presence of substantial decreases in environmental $\mathrm{pH}$. Aplysia californica has been shown to have strong control of tissue $\mathrm{pH}$, utilizing carbonic anhydrase and urease to tightly control acid-base balance and thus aragonite deposition in the statocyst (Pedrozo et al., 1997). Our results suggest that A. punctata can similarly regulate shell formation, perhaps utilizing the same enzymes; and, under even this extreme OA scenario, calcification was not compromised. In molluscs, the tissue fluid around calcification sites is commonly at a much lower $\mathrm{pH}$ than that of the surrounding seawater, yet lower seawater $\mathrm{pH}$ can still cause reduced shell integrity (Melzner et al., 2011). Likely it is not simply a case of $\mathrm{pH}$ or $\mathrm{pCO}_{2}$ value per se that causes reduced calcification; overall energy budget and food limitation may be the critical factor in the energy required to maintain calcification (Melzner et al., 2011).

The shell of $A$. punctata is small in comparison to the size of the animal, and so shell growth and calcification are likely to comprise a minor part of an individual's overall energy budget. However, even under the extreme $\mathrm{pH}$ conditions of our study, reduced calcification was not observed, which suggests that the process is highly controlled and important enough to be maintained despite the potential energetic costs. We could not quantify the calcium content of the shell part that had been present before exposure to the experimental OA treatment, but visual inspection through dissection and brightness of fluorescence showed no obvious distinction between the two treatment groups, and shell calcification was not correlated with any morphometric or physiological parameters (Fig. 3). Our data did suggest the possibility that growth was suppressed along with metabolism in low $\mathrm{pH}$, as shown by the narrowing of the shell border matrix, although under statistical analysis this was a marginally non-significant difference (Kruskal-Wallis $\mathrm{H}$ test, $P=0.06$ ). Construction of proteinaceous "scaffolding" such as this may be the critical shell-building process that is disrupted under climate change scenarios via energetic trade-offs or shortfalls, rather than the disruption to calci- fication caused by external $\mathrm{pH}$ changes. Disruption to calcification, however, may have been observed under longer exposures, which is typical with longer acclimation (Melzner et al., 2011). Such a disruption could potentially be explained by ongoing impacts to growth of the proteinaceous matrix; calcification would eventually be disrupted because growth of the matrix is a prerequisite, and with less matrix there would be less calcification.

These patterns suggest a potential deterministic growth pattern, where shell calcification occurs at a steady pace throughout the animal's life and in variable conditions of health or environment. This increase in the relative energetic investment in shell growth under hypercapnia has been well documented in the cephalopod mollusc Sepia officinalis (Gutowska et al., 2010). In that species, hypercapnic juveniles grow more slowly in body size, and though their cuttlebones are denser, they grow the same deterministic number of laminae within the shell structure (Sigwart et al., 2015). This type of deterministic shell growth may be present in many molluscs and shell-bearing invertebrates that have the physiological capacity to maintain calcification in undersaturated conditions. Hypercalcification, or growth of a denser shell in response to experimental OA conditions, has also been observed in several other groups, including fish and crustaceans (Ries et al., 2009), and attributed to the strong acid-base regulatory physiology in these animals. But such capacity may be present in a broader suite of animals.

The technical problems of achieving fully replicated experimental designs is a recognized issue in ocean acidification research, where there is concern that apparent effects may be due to variability rather than induced change (Wernberg et al., 2012; Cornwall and Hurd, 2015). The results of the present study likewise did not include independent treatment replication and also involved a relatively brief acclimation duration. Tank effects could have caused the metabolic depression that we observed in the low $\mathrm{pH}$ treatment group; however, lower metabolism is an established typical response of marine invertebrates to short-term experimental OA (Christensen et al., 2011). Similarly, any differences in shell growth could disappear over longer timescales. Other OA studies have utilized similar or shorter timescales and observed relevant biological responses (e.g., Catarino et al., 2012, 19 days; Zittier et al., 2013, 12 days; Ferrari et al., 2015, 4 days), and these brief timescales are also relevant to responses under short-term fluctuations such as under low $\mathrm{pH}$ brought about by upwelling, particularly given that such fluctuations are likely to be more frequent and severe in the near-future ocean. The ongoing process of calcification, which did not appear to differ across $\mathrm{pH}$ levels, is direct observational evidence that this process can be maintained under an extreme OA scenario during acute short-term exposures, which are long enough to observe noticeable shell growth. 
Under even extreme ocean acidification scenarios, Aplysia punctata can maintain shell calcification despite a significant reduction in metabolic rate, although overall shell growth may be disrupted. The ongoing energetic consequences of ocean acidification in the long term to this species and other shallow coastal invertebrates remain uncertain. The capacity for invertebrates to maintain calcification under suboptimal abiotic conditions with strong internal acid-base regulation may be more widespread than has been recognized to date.

\section{Acknowledgments}

We thank Bengt Lundve for help with acquiring specimens and maintaining aquarium facilities, and Ian F. Smith for the photograph of a live A. punctata in Figure 1. This research was supported by the European CommunityResearch Infrastructure Action under the FP7 "Capacities" Programme ASSEMBLE (227799) for fieldwork and laboratory work at the Sven Lovén Centre for Marine Sciences, Kristineberg, and by the Queen's University Belfast, Marine Laboratory. SD is funded by the Centre for Marine Evolutionary Biology, CeMEB (http://www.cemeb.science.gu. se/) and supported by a Linnaeus grant from the Swedish Research Councils. Two anonymous reviewers provided suggestions that greatly improved the final manuscript.

\section{Literature Cited}

Appelhans, Y. S., J. Thomsen, S. Opitz, C. Pansch, F. Melzner, and M. Wahl. 2014. Juvenile sea stars exposed to acidification decrease feeding and growth with no acclimation potential. Mar. Ecol. Prog. Ser. 509: 227-239.

Beesley, P. L., G. J. B. Ross, and A. Wells, eds. 1998. Mollusca: the Southern Synthesis. Fauna of Australia, Vol. 5. CSIRO Publishing, Melbourne.

Burnell, O. W., B. D. Russell, A. D. Irving, and S. D. Connell. 2013. Eutrophication offsets increased sea urchin grazing on seagrass caused by ocean warming and acidification. Mar. Ecol. Prog. Ser. 485: 37-46.

Carefoot, T. H. 1987. Aplysia: its biology and ecology. Oceanogr. Mar. Biol. Аnпи. Rev. 25: 167-284.

Carefoot, T. H. 1988. Diet and its effect on oxygen uptake in the sea hare Aplysia. J. Exp. Mar. Biol. Ecol. 114: 275-287.

Carey, N., and J. D. Sigwart. 2014. Size matters: plasticity in metabolic scaling shows body-size may modulate responses to climate change. Biol. Lett. 10: 20140408.

Carey, N., J. D. Sigwart, and J. G. Richards. 2013. Economies of scaling: more evidence that allometry of metabolism is linked to activity, metabolic rate and habitat. J. Exp. Mar. Biol. Ecol. 439: 7-14.

Carey, N., S. Dupont, B. Lundve, and J. D. Sigwart. 2014. One size fits all: stability of metabolic scaling under warming and ocean acidification in echinoderms. Mar. Biol. 161: 2131-2142.

Carey, N., J. Harianto, and M. Byrne. 2016. Sea urchins in a high $\mathrm{CO}_{2}$ world: partitioned effects of body-size, ocean warming and acidification on metabolic rate. J. Exp. Biol. 219: 1178-1186.

Catarino, A. I., M. Bauwens, and P. Dubois. 2012. Acid-base balance and metabolic response of the sea urchin Paracentrotus lividus to different seawater $\mathrm{pH}$ and temperatures. Environ. Sci. Pollut. Res. Int. 19: $2344-2353$.

Christensen, A. B., H. D. Nguyen, and M. Byrne. 2011. Thermotoler- ance and the effects of hypercapnia on the metabolic rate of the ophiuroid Ophionereis schayeri: inferences for survivorship in a changing ocean. J. Exp. Mar. Biol. Ecol. 403: 31-38.

Cornwall, C. E., and C. L. Hurd. 2015. Experimental design in ocean acidification research: problems and solutions. ICES J. Mar. Sci. DOI: 10.1093/icesjms/fsv118.

Croll, R. P. 1985. Sensory control of respiratory pumping in Aplysia californica. J. Exp. Biol. 177: 15-27.

Davis, A. R., D. Coleman, A. Broad, M. Byrne, S. A. Dworjanyn, and R. Przeslawski. 2013. Complex responses of intertidal molluscan embryos to a warming and acidifying ocean in the presence of UV radiation. PLoS One 8: e55939.

Dickson, A. G., and F. J. Millero. 1987. A comparison of the equilibrium constants for the dissociation of carbonic acid in seawater media. Deep-Sea Res. Part A Oceanogr. Res. Pap. 34: 1733-1743.

Dieringer, N., J. Koester, and K. R. Weiss. 1978. Adaptive changes in heart rate of Aplysia californica. J. Comp. Physiol. 123: 11-21.

Dionísio, G., R. Rosa, M. C. Leal, S. Cruz, C. Brandão, G. Calado, J. Serôdio, and R. Calado. 2013. Beauties and beasts: a portrait of sea slugs aquaculture. Aquaculture 408-409: 1-14.

Donovan, D. A., S. C. Pennings, and T. H. Carefoot. 2006. Swimming in the sea hare Aplysia brasiliana: cost of transport, parapodial morphometry, and swimming behavior. J. Exp. Mar. Biol. Ecol. 328: $76-86$.

Du, S. J., V. Frenkel, G. Kindschi, and Y. Zohar. 2001. Visualizing normal and defective bone development in zebrafish embryos using the fluorescent chromophore calcein. Dev. Biol. 238: 239-246.

Dupont, S., O. Ortega-Martínez, and M. Thorndyke. 2010. Impact of near-future ocean acidification on echinoderms. Ecotoxicology 19: $449-462$.

Ferrari, M. C. O., P. L. Munday, J. L. Rummer, M. I. McCormick, K. Corkill, S.-A. Watson, B. J. M. Allan, M. G. Meekan, and D. P. Chivers. 2015. Interactive effects of ocean acidification and rising sea temperatures alter predation rate and predator selectivity in reef fish communities. Glob. Chang. Biol. 21: 1848-1855.

Fofonoff, N. P., and R. C. Millard, Jr. 1983. Algorithms for Computation of Fundamental Properties of Seawater, UNESCO Technical Papers in Marine Science. UNESCO Division of Marine Sciences, Paris.

Frieder, C. A., S. H. Nam, T. R. Martz, and L. A. Levin. 2012. High temporal and spatial variability of dissolved oxygen and $\mathrm{pH}$ in a nearshore California kelp forest. Biogeosciences 9: 3917-3930.

Gaylord, B., T. M. Hill, E. Sanford, E. A. Lenz, L. A. Jacobs, K. N. Sato, A. D. Russell, and A. Hettinger. 2011. Functional impacts of ocean acidification in an ecologically critical foundation species. $\underline{\text { J. Exp. }}$ Biol. 214: $2586-2594$.

Glazier, D. S. 2009. Activity affects intraspecific body-size scaling of metabolic rate in ectothermic animals. J. Comp. Phvsiol. B 179: 821828 .

Glazier, D. S. 2010. A unifying explanation for diverse metabolic scaling in animals and plants. Biol. Rev. 85: 111-138.

Gutowska, M. A., F. Melzner, H. O. Pörtner, and S. Meier. 2010. Cuttlebone calcification increases during exposure to elevated seawater $p \mathrm{CO}_{2}$ in the cephalopod Sepia officinalis. Mar. Biol. 157: 1653-1663.

Hall-Spencer, J. M., R. Rodolfo-Metalpa, S. Martin, E. Ransome, M. Fine, S. M. Turner, S. J. Rowley, D. Tedesco, and M.-C. Buia. 2008. Volcanic carbon dioxide vents show ecosystem effects of ocean acidification. Nature 454: 96-99.

Harvey, B. P., D. Gwynn-Jones, and P. J. Moore. 2013. Meta-analysis reveals complex marine biological responses to the interactive effects of ocean acidification and warming. Ecol. Evol. 3: 1016-1030.

Heffner, R. A., M. J. Butler, and C. K. Reilly. 1996. Pseudoreplication revisited. Ecology 77: 2558-2562. 
Hunt, A. B. 1877. On some large Aplysiae taken in Torbay in 1875. Trans. Devonsh. Assoc. 9: 400-403.

IPCC. 2014. Climate Change 2014: Synthesis Report. Contribution of Working Groups I, II and III to the Fifth Assessment Report of the Intergovernmental Panel on Climate Change, Core Writing Team, R. K. Pachauri, and L. A. Meyer, eds. IPCC, Geneva, Switzerland. $151 \mathrm{p}$.

Kandel, E. R., Y. Dudai, and M. R. Mayford. 2014. The molecular and systems biology of memory. Cell 157: 163-186.

Krakauer, J. M. 1974. A method for estimating live weight and body length from the shell Aplysia willcoxi Heilprin, 1886. Veliger 16: 396-398.

Kroeker, K. J., F. Micheli, M. C. Gambi, and T. R. Martz. 2011. Divergent ecosystem responses within a benthic marine community to ocean acidification. Proc. Natl. Acad. Sci. USA 108: 14515-14520.

Kwiatkowski, L., B. Gaylord, T. Hill, J. Hosfelt, K. J. Kroeker, Y. Nebuchina, A. Ninokawa, A. D. Russell, E. B. Rivest, M. Sesboüé et al. 2016. Nighttime dissolution in a temperate coastal ocean ecosystem increases under acidification. Sci. Rep. 6: 22984.

Lighton, J. R. B. 2008. Measuring Metabolic Rates: a Manual for Scientists. Oxford University Press, Oxford.

Marsden, I. D., S. E. Shumway, and D. K. Padilla. 2012. Does size matter? The effects of body size and declining oxygen tension on oxygen uptake in gastropods. J. Mar. Biol. Assoc. U.K. 92: 1603-1617.

Mehrbach, C., C. H. Culberson, J. E. Hawley, and R. M. Pytkowicx. 1973. Measurement of the apparent dissociation constants of carbonic acid in seawater at atmospheric pressure. Limnol. Oceanogr. 18: 897907.

Melzner, F., P. Stange, K. Trübenbach, J. Thomsen, I. Casties, U. Panknin, S. N. Gorb, and M. A. Gutowska. 2011. Food supply and seawater $p \mathrm{CO}_{2}$ impact calcification and internal shell dissolution in the blue mussel Mytilus edulis. PLoS One 6: e24223.

Melzner, F., J. Thomsen, W. Koeve, A. Oschlies, M. A. Gutowska, H. W. Bange, H. P. Hansen, and A. Körtzinger. 2013. Future ocean acidification will be amplified by hypoxia in coastal habitats. Mar. Biol. 160: $1875-1888$.

Moulin, L., P. Grosjean, J. Leblud, A. Batigny, M. Collard, and P. Dubois. 2015. Long-term mesocosms study of the effects of ocean acidification on growth and physiology of the sea urchin Echinometra mathaei. Mar. Environ. Res. 103: 103-114.

Mucci, A. 1983. The solubility of calcite and aragonite in seawater at various salinities, temperatures, and one atmosphere total pressure. Am. J. Sci. 238: 780-799.

Newcomb, L. A., M. Milazzo, J. M. Hall-Spencer, and E. Carrington. 2015. Ocean acidification bends the mermaid's wineglass. Biol. Lett. 11: 20141075 .

Oksanen, L. 2001. Logic of experiments in ecology: is pseudoreplication a pseudoissue? Oikos 94: 27-38.

Orr, J. C., V. J. Fabry, O. Aumont, L. Bopp, S. C. Doney, R. A. Feely, A. Gnanadesikan, N. Gruber, A. Ishida, F. Joos et al. 2005. Anthropogenic ocean acidification over the twenty-first century and its impact on calcifying organisms. Nature 437: 681-686.

Ouisse, V., P. Riera, A. Migné, C. Leroux, and D. Davoult. 2012. Food web analysis in intertidal Zostera marina and Zostera noltii communities in winter and summer. Mar. Biol. 159: 165-175.

Pedrozo, H. A., Z. Schwartz, D. D. Dean, J. L. Harrison, J. W. Campbell, M. L. Wiederhold, and B. D. Boyan. 1997. Evidence for the involvement of carbonic anhydrase and urease in calcium carbonate formation in the gravity-sensing organ of Aplysia californica. $\underline{\text { Calcif. }}$ Tissue Int. 61: 247-255.

Peretz, B., and L. Adkins. 1982. An index of age when birthdate is unknown in Aplysia californica: shell size and growth in long-term maricultured animals. Biol. Bull. 162: 333-344.

Queirós, A. M., J. A. Fernandes, S. Faulwetter, J. Nunes, S. P. S. Rastrick, N. Mieszkowska, Y. Artioli, A. Yool, P. Calosi, C. Arvanitidis et al. 2015. Scaling up experimental ocean acidification and warming research: from individuals to the ecosystem. Glob. Chang. Biol. 21: $130-143$.

R Core Team. 2015. $R:$ a Language and Environment for Statistical Computing. R Foundation for Statistical Computing, Vienna. Available: http://www.R-project.org/ [2016, Jan. 5].

Ries, J. B., A. L. Cohen, and D. C. McCorkle. 2009. Marine calcifiers exhibit mixed responses to $\mathrm{CO}_{2}$-induced ocean acidification. Geology 37: 1131-1134.

Rodolfo-Metalpa, R., F. Houlbrèque, É. Tambutté, F. Boisson, C. Baggini, F. P. Patti, R. Jeffree, M. Fine, A. Foggo, J.-P. Gattuso et al. 2011. Coral and mollusc resistance to ocean acidification adversely affected by warming. Nat. Clim. Change 1: 308-312.

Russell, M. P., and L. M. Urbaniak. 2004. Does calcein affect estimates of growth rates in sea urchins? Pp. 53-57 in Echinoderms: Munchen. Proceedings of the 11th International Echinoderm Conference, 6-10 October 2003, T. Heinzeller and J. H. Nebelsick, eds. CRC Press, Munich.

Saderne, V., P. Fietzek, and P. M. J. Herman. 2013. Extreme variations of $p \mathrm{CO}_{2}$ and $\mathrm{pH}$ in a macrophyte meadow of the Baltic Sea in summer: evidence of the effect of photosynthesis and local upwelling. PLoS One 8: e62689.

Sattelle, D. B., and S. D. Buckingham. 2006. Invertebrate studies and their ongoing contributions to neuroscience. Invertebr. Neurosci. 6: $1-3$.

Schneider, C. A., W. S. Rasband, and K. W. Eliceiri. 2012. NIH Image to ImageJ: 25 years of image analysis. Nat. Methods 9: 671-675.

Sigwart, J. D., G. Lyons, A. Fink, M. A. Gutowska, D. Murray, F. Melzner, J. D. R. Houghton, and M. Y. Hu. 2015. Elevated $p \mathrm{CO}_{2}$ drives lower growth and yet increased calcification in the early life history of the cuttlefish Sepia officinalis (Mollusca: Cephalopoda). ICES J. Mar. Sci. Doi: 10.1093/icesjms/fsv188.

Sokal, R. R., and F. J. Rolhf. 1995. Biometry, 3rd ed. W. H. Freeman, New York.

Suckling, C. C., M. S. Clark, J. Richard, S. A. Morley, M. A. S. Thorne, E. M. Harper, and L. S. Peck. 2015. Adult acclimation to combined temperature and $\mathrm{pH}$ stressors significantly enhances reproductive outcomes compared to short-term exposures. J. Anim. Ecol. 84: 773-784.

Thomsen, J., M. A. Gutowska, J. Saphörster, A. Heinemann, K. Trübenbach, J. Fietzke, C. Hiebenthal, A. Eisenhauer, A. Körtzinger, M. Wahl et al. 2010. Calcifying invertebrates succeed in a naturally $\mathrm{CO}_{2}$-rich coastal habitat but are threatened by high levels of future acidification. Biogeosciences 7: 3879-3891.

Tonejc, A. M., D. Medaković, S. Popović, A. Jaklin, M. Bijelić, and I. Lončarek. 2014. Biomineralization in the sea hare Aplysia punctata initiated by nano-dolomite. Croat. Chem. Acta 87: 143-152.

Usuki, I. 1981. Growth characteristics of the early juvenile of Aplysia juliana collected in winter. Venus 39: 212-223.

Wernberg, T., D. A. Smale, and M. S. Thomsen. 2012. A decade of climate change experiments on marine organisms: procedures, patterns and problems. Glob. Chang. Biol. 18: 1491-1498.

Zittier, Z. M. C., T. Hirse, and H. O. Pörtner. 2013. The synergistic effects of increasing temperature and $\mathrm{CO}_{2}$ levels on activity capacity and acid-base balance in the spider crab, Hyas araneus. Mar. Biol. 160: 2049-2062. 